\title{
Analisis Kontribusi Accounting Dan Akuntan Terhadap Perkembangan Dan Pengungkapan Sustainable Reporting
}

\author{
INOVA FITRI SIREGAR ${ }^{1}$; RINAYANTI RASYAD ${ }^{2}$; ZAHARMAN ${ }^{3}$ \\ Universitas Lancang Kuning \\ Jln. Yos Sudarso KM 08 Rumbai Pekanbaru \\ E-mail : siregar_inovafitri@unilak.ac.id
}

\begin{abstract}
This study aims to find out how Accounting and Accountants contribute to Sustainable Reporting and this study aims to see how accountants are required to be able and have an understanding of accounting based on Sustainable reporting and this is all closely related to the learning needs of accounting students, meaning by seeing how much accounting knowledge and accountants for the development of Sustainable reporting in the new department, this research is expected to be able to see the needs of learning, Sustainable reporting what is really what the company is really implementing at this time. The method in this study was purposive sampling and tested how Accounting and Accountants contribute to Sustainable Reporting so that it can be seen how Accounting and Accountants contribute to Sustainable Reporting. The sample used is all Accounting and Accountants in the city of Pekanbaru. There are 60 Accounting and Accountants who were sampled in this study. The results of this study are increasing escalation of environmental damage, climate change and global warming, political and market pressures to state leaders and business people to implement the Green Economy concept and Green Business in the development of the national economy / business increasing by $70 \%$
\end{abstract}

Keywords: Accounting, Sustainable Reporting

Sistematika pembangunan berkelanjutan yang terdiri atas tiga konstruksi yaitu ekonomi, sosial, dan lingkungan (Cato, 2009 hal. 36-37; Adams, 2006); tidak terlepas dari aktivitas ekonomi yang meliputi kegiatan produksi dan konsumsi sumber daya. Pandangan ekonomi yang mengakar pada sebuah analisis efektivitas dan efisiensi menuntut perkembangan ilmu pengetahuan dan inovasi teknologi untuk meningkatkan optimalisasi penggunaan sumber daya. Hal ini berujung pada pelestarian sistem lingkungan yang mengarah pada sebuah kesetimbangan ekologi 3dan pembangunan berkelanjutan

$$
\text { Laporan }
$$

Akuntansi

Berkesinambungan merupakan bentuk tanggung jawab perusahaan sebagai pemangku kepentingan (stakeholders) atas pemanfaatan lingkungan. Laporan Akuntansi Berkesinambungan merupakan bagian dari keseluruhan pelaporan keuangan perusahaan yang disampaikan kepada publik pada setiap periode tertentu. Rerangka konseptual Laporan Akuntansi
Berkesinambungan saat ini sedang dalam proses review publik yang akan segera diimplementasikan pada periode mendatang. Laporan Akuntansi Berkesinambungan ini dirancang oleh Dewan Standar Akuntansi Berkelanjutan/Sustainability Accounting Standards Board (SASB) di Amerika Serikat (AS) sebagai pelengkap pengungkapan informasi kepada publik selain laporan keuangan yang diwajibkan oleh Securities and Exchange Commission (SEC) khususnya bagi perusahaan yang terdaftar di AS.

Indonesia termasuk negara yang yang mengkiblat pada peraturan pengungkapan pelaporan keuangan di AS sebagaimana adopsi standar pelaporan akuntansi keuangan internasional (International Financial Reporting Standards/IFRS) sehingga dalam periodeperiode mendatang juga akan melakukan adopsi peraturan baru seperti Laporan Akuntansi Berkesinambungan. Sementara ini laporan pertanggungjawaban 
lingkungan hanya bersifat sebagai pemanis laporan keuangan perusahaan. Sifatnya yang masih sukarela sejauh ini menyebabkan tidak semua perusahaan bersedia menyampaikan laporan pertanggungjawaban sosial termasuk aktivitas pelestarian sumber daya alam secara lengkap dan komprehensif. Pada umumnya laporan ini hanya memuat kegiatan Corporate Social Responsibilty (CSR) perusahaan dengan hanya mencantumkan satu-dua paragraf yang memuat tentang pelestarian ekosistem di wilayah operasional perusahaan.

Konsep Laporan Akuntansi

Berkesinambungan sebagaimana dinyatakan dalam SASB (2013) terdiri atas beberapa klasifikasi berdasarkan jenis industri seperti industri kesehatan, keuangan, teknologi dan komunikasi, sumber daya alam tak-terbarukan, transportasi, jasa, transformasi $s$ '[bbnumber daya, barang konsumsi, sumber daya alam terbarukan dan energi alternatif, serta infrastruktur. Sustainability Reporting tidak saja memuat informasi kinerja keuangan tetapi juga informasi nonkeuangan. Lebih jauh penelitian yang dilaku- kan oleh oleh Tomo (2011) menunjukkan ada kesenjangan atas nilai perusahaan jika hanya memperhatikan aspek keuangan saja. Penelitian yang dilakukan atas nilai pasar organisasi menunjukkan pergerakan yang cukup signifikan, dimana nilai pasar perusahaan tahun 1975 sebanyak $83 \%$ di tentukan oleh aspek keuangan dan $17 \%$ aspek nonkeuangan. Hal ini telah berubah drastis dengan data tahun 2009, di mana nilai pasar organisasi bisnis ditentukan hanya $19 \%$ saja aspek keuangan dan sisanya $81 \%$ adalah aspek non-keuangan

Aspek non-keuangan ini yang memungkin- kan perusahaan bisa menghasilkan kinerja yang berkesinambungan (sustainable performance). Sustainable performance merupakan kinerja yang dihasilkan dengan menyeimbangkan ketiga aspek berupa people-planet-profit, yang dikenal dengan konsep Triple Bottom Line (TBL). Sustainability report merupakan praktek pengukuran, peng- ungkapan dan upaya akuntabilitas dari sustaina- bility activities yang bertujuan untuk tercapainya sustainable development (Global Reporting Initia- tive, 2011). Perusahaan yang mempertimbangkan pengembangan yang berkelanjutan (sustainable development) akan dapat meningkatkan nilai perusahaan karena dukungan yang diperoleh dari stakeholder baik internal maupun eksternal, seperti konsumen, karyawan, investor, regulator, pemasok maupun kelompok lainnya. Kemampuan perusahaan untuk mengkomunikasikan kegiatan dan kinerja sosial dan lingkungan secara efektif dalam sustainability report dinilai penting untuk keberhasilan jangka panjang

Permasalahannya terletak pada bagaimana Accounting dan Profesional Akuntan memandang tujuan dan solusi dari transformasi dari aspek profit saja (single bottom line) menjadi aspek profit, lingkungan dan sosial (triple bottom line). Sistematika dalam penelitian ini adalah review dan literatur mengenai pengembangan keberlanjutan, kemudian isu pertanggungjawaban perusahaan, laporan keberlanjutan.

Korporasi, komunitas daan lingkungan merupakan bagian integral dan merupakan bagian yang sangat berhubungan dengan yang lainnya. Dengan kata lain keberlanjutan adalah bagaimana kemampuan suatu perusahaan untuk bisa bertahan dalam jangka panjang.

Ide utama teori institusional adalah terbentuknya organisasi karena adanya tekanan lingkungan institusional yang menyebabkan terjadinya institusionalisasi. Sehingga organisasi yang mengutamakan legitimasi terbentuk oleh lingkungan institusional yang ada di sekitarnya karena organisasi tersebut memiliki kecenderungan untuk berusaha menyesuaikan diri pada harapan eksternal atau harapan sosial dimana 
organisasi berada (DiMaggio dan Powell, 1983). Kegagalan memenuhi norma/harapan tersebut akan mengancam legitimasi, sumberdaya, bahkan survival perusahaan (Lourenco, et. al., 2012).

Menurut DiMaggio dan Powell (1983) proses legitimasi yang sering dilakukan oleh organisasi, yaitu melalui tekanan negara-negara, serta pernyataanpernyataan. Maka kekhususan teori institusional tersebut terdapat dalam paradigma norma-norma berupa regulasi, dan legitimasi, cara berpikir serta semua fenomena sosio-kultural yang konsisten dengan pelaksanaan instrumen pada organisasi.

Tanggung jawab sosial dan lingkungan perusahaan dipengaruhi oleh kondisi institusional di wilayah operasi perusahaan yang meliputi peraturan perundang-undangan, nilai dan norma sosial, serta pengetahuan lokal (pengalaman). Institusionalisasi aturan dan norma menjadi fokus utama dari "penyesuaian" dalam strategi perusahaan yang melakukan pelaporan keberlanjutan dan memungkinkan perusahaan mendapatkan maupun mempertahankan legitimasi Frynas (2009). Oleh karena itu, perusahaan akan mengupayakan beragam cara yang dipandang perlu dalam proses legitimasi. DiMaggio dan Powell (1983) kemudian mengidentifikasikan penyesuaian yang dilakukan oleh organisasi dalam teori institusi, yakni penyesuaian kategorial, penyesuaian struktural, penyesuaian prosedural, dan penyesuaian personil.

Sustainability report memiliki definisi yang beragam, menurut Elkington (1997), sustainability report berarti laporan yang memuat tidak saja informasi kinerja keuangan tetapi juga informasi non keuangan yang terdiri dari informasi aktivitas sosial dan lingkungan yang memungkinkan per- usahaan bisa bertumbuh secara berkesinambung- an (sustainable performance). Saat ini implementasi sustainability report di Indonesia di- dukung oleh aturan pemerintah seperti
Undang- Undang Perseroan Terbatas (PT) nomer 40 tahun 2007.

Praktek pelaporan aktivitas tanggung jawab sosial dan lingkungan yang diungkapkan melalui sustainability report membutuhkan pedoman. Salah satu pedoman yang dapat digunakan adalah Global Reporting Initiative (GRI). Di Indonesia, pedoman ini digunakan oleh NCSR,

Sustainability report juga dapat digunakan oleh institusi pemerintah misalnya dari pihak kementerian lingkungan untuk membuat penilai- an atas kinerja perusahaan terhadap lingkungan dalam setiap pelaporan organisasi. Seperti halnya di Indonesia, peraturan dalam pengungkapan CSR dapat ditemukan dalam aturan yang dikeluarkan oleh Undang-Undang Nomor 40 tahun 2007 tentang Perseroan Terbatas (PT), khususnya pasal 74 Sustainability report dalam pedoman GRI versi 3.1 terbagi menjadi tiga dimensi, yaitu aspek Ekonomi (EC), Lingkungan-Environment (EN) dan Sosial. Aspek sosial terdiri dari empat sub-dimensi yaitu: Tenaga Kerja Labor (LA), Hak Asasi Manusia-Human Rights (HR), Masyarakat - Society (SO), dan Tanggung Jawab Produk - Product Responsibility (PR).

Penelitian ini menggunakan GRI versi 3.1, belum mengguna- kan versi 4.0, hal ini disebabkan karena semua sampel penelitian ini masih menggunakan sustainability report dengan standar GRI Dalam Calizkan 2014, menyatakan bahwa konsep yang digunakan dalam hubungan keberlanjutan

\section{METODE}

Lokasi penelitian adalah orang atau peristiwa yang sedang diteliti. Adapun yang menjadi objek dalam penelitian ini Perusahaan perusahaan yang masuk kriteria Perusahan, Dosen, KAP dan KJA yang ada dikota Pekanbaru. Populasi adalah sekelompok orang, kejadian atau segala sesuatu yang mempunyai karakteristik tertentu sedangkan sampel adalah sebagian 
dari elemen populasi (Indriantoro dan Supomo:2002:15). Menurut Sugiyono (2005) sampel adalah sebagian dari jumlah dan karakteristik yang dimiliki oleh suatu populasi.

Populasi dalam penelitian ini adalah seluruh Perusahan, Dosen, KAP dan KJA yang ada dikota Pekanbaru. Yang menjadi sampel dalam penelitian ini berjumlah 60 Perusahaan-Perusahan, Dosen, KAP dan KJA yang ada dikota Pekanbaru. Teknik pengambilan sampel dalam penelitian ini adalah metode purposive sampling. Metode tersebut merupakan pemilihan sampel dimana populasi yang akan dijadikan sampel yang dikehendaki oleh peneliti sesuai dengan tujuan penelitian (Ghazali:2006). Dengan mempertimbangkan arah dan tujuan penelitian, kriteria yang ditetapkan adalah : Perusahaan yang diteliti adalah Perusahan, Dosen, KAP dan KJA yang ada dikota Pekanbaru

Dengan memperhatikan kriteria diatas, dipilih keseluruhan sampel yang diambil berjumlah 60 yaitu berasal dari Perusahan, Dosen, KAP dan KJA yang ada dikota Pekanbaru sebagai sampel penelitian.

Data yang digunakan dalam penelitian ini adalah data sekunder, yaitu data yang diperoleh dari pihak lain berupa kuesioner. Data yang digunakan dalam penelitian ini berupa kuesioner dari Perusahan, Dosen, KAP dan KJA yang ada dikota Pekanbaru.

Analisis data adalah proses penyederhanaan data ke dalam bentuk yang mudah dibaca dan diinterpretasikan. Dalam mengolah dan menganalisis data digunakan analisis dan pengujian kuantitatif. Analisis kuantitatif menyangkut pengolahan data dengan menggunakan rumus-rumus yang dapat diterapkan untuk menganalisis data. Tujuan dari analisis ini adalah untuk mendapatkan informasi yang relevan yang terkandung dalam data tersebut dan menggunakan hasilnya untuk memecahkan suatu masalah.

Metode analisis data yang digunakan dalam penelitian ini adalah metode analisis deskriptif, dengan melihat hasil dari kuesioner yang telah diberikan kepada responden yaitu Perusahan, Dosen, KAP dan KJA yang ada dikota Pekanbaru. Statistika deskriptif ini merupakan metodemetode yang berkaitan dengan pengumpulan, peringkasan, dan penyajian suatu data sehingga memberikan informasi yang berguna dan juga menatanya ke dalam bentuk yang siap untuk dianalisis. Dengan kata lain, statistika deskriptif ini merupakan fase yang membicarakan mengenai penjabaran dan penggambaran termasuk penyajian data. Dalam fase ini dibahas mengenai ukuran-ukuran statistik seperti ukuran pusat, ukuran sebaran, dan ukuran lokasi dari persebaran / distribusi data.

Adapun analisis statistika deskriptif ini memiliki tujuan untuk memberikan gambaran (deskripsi) mengenai suatu data agar data yang tersaji menjadi mudah dipahami dan informatif bagiorang yang membacanya. Statistika deskriptif menjelaskan berbagai karakteristik data seperti rata-rata (mean), jumlah (sum) simpangan baku (standard deviation), varians (variance), rentang (range), nilai minimum dan maximum dan sebagainya.

\section{HASIL}

Hasil penelitian menunjukkan bahwa Laporan keuangan yang dihasilkan dari proses Akuntansi dan dikerjakan oleh para Akuntan hanya menyajikan informasi keuangan kepara para pemakai, sedangkan informasi sosial dan lingkungan diabaikan dalam proses akuntansi, menurut Andreas Lako dalam bukunya Green Accounting, bahwa Akuntan hanya menyajikan informasi keuangan saja tapi mengabaikan proses akuntansi yaitu proses informasi sosial dan informasi sosial, hal ini dibuktikan dengan banyak kebakaran hutan, pelapis ozon yang semakin menipis, pencemaran limbah indutri yang pada saat ini telah masuk fase bahaya. Seharusnya sebagai Akuntan harus responsive terhadap informasi sosial dan informasi lingkungan yang berdampak kepada hasil produk yang dihasilkan oleh setiap perusahaan, dari hasil kuesioner yang disebarkan kepada 
responden terdapat $35 \%$ dan $15 \%$ yang menjawab setuju dan sangat setuju atas pernyataan dibawah sedangkan terdapat $11 \%$ yang menjawab sangat tidak setuju dimana proses Akuntansi dan dikerjakan oleh para Akuntan hanya menyajikan informasi keuangan kepara para pemakai, sedangkan informasi sosial dan lingkungan diabaikan dalam proses akuntansi.

Peningkatan eskalasi kerusakan lingkungan, perubahan iklim dan pemanasan global, tekanan politik dan pasar kepada para pemimpin negara dan pebisnis untuk menerapkan konsep Green Economy dan Green Business dalam pembangunan ekonomi/bisnis nasional kian meningkat sebanyak $70 \%$.

Responden yang terdiri dari Akuntan diperusahaan, Dosen dan Akuntan KAP dan KJA telah memahami konsep Sustainable Reporting, dan banyak juga yang masih belum memahami pengalokasian beban CSR tersebut.

\section{PEMBAHASAN}

Faktor yang mendorong perusahaan melakukan CSR adalah berkaitan dengan kritik organisasi masyarakat sipil terhadap kinerja sosial dan lingkungan perusahaan, dari pertanyaan diatas responden yang menjawab sangat setuju sebanyak 63,3\% atau sebanyak 39 orang responden.

Pertanyaan kedua adalah apakah CSR adalah kewajiban bagi perusahaan merupakan pertanyaan berikutnya yang akan ditanyakan kepada responden, dimana pihak perusahaan harus mengetahui bahwa CSR adalah laporan yang wajib dan harus diungkapkan oleh setiap perusahaan, dari hasil kuesioner yang diberikan kepada 60 orang responden, hampir $73 \%$ atau 44 orang yang setuju bahwa CSR adalah kewajiban setiap perusahaan untuk melaporkan setiap tahunnya. Akan tetapi terdapat 20\% atau sebanyak 12 orang responden yang sangat tidak setuju yang menyatakan CSR adalah kewajiban setiap Perusahaan, hal ini terjadi dikarenakan bahwa sebenarnya sifat CSR tidak wajib atau bersifat sukarela.

Kemudian pertanyaan berikutnya adalah CSR hanya menambah beban perusahaan dan yang meyakini kinerja sosial penting dan berhubungan positif dengan keuntungan finansial, dari pernyataan diatas adalah didalam Laporan keberlanjutan (Sustainable Reporting) CSR dimasukkan kedalam beban biaya lingkungan yang terdiri dari biaya penilaian, biaya pencegahan, biaya kegagalan eksternal dan biaya kegagalah internal. Dari hasil kuesioner yang diberikan terdapat 33\% menjawab tidak tau (ragu-ragu), setuju dan sangat setuju, dan $10 \%$ atau sebanyak 6 orang responden yang tidak menyetujui bahwa CSR termasuk beban yang akan ditanggung oleh perusahaan akan tetapi akan berpengaruh terhadap keuntungan financial perusahaan. Pertanyaan kelima adalah Sustainable Reporting Merupakan komitmen perseroan untuk berperan serta mewujudkan pembangunan ekonomi berkelanjutan guna meningkatkan kualitas kehidupan masyarakat (people) dan lingkungan (planet) maupun perusahaan itu sendiri (profit). Artinya dengan adalah pelaporan yang baik dan dilaporkan setiap tahun oleh perusahaan, maka akan dapat mewujudkan pembangunan ekonomi yang terus berlanjut dan menunjukkan bahwa perusahaan telah responsive dan bertanggung jawab atas usaha yang perusahaan lakukan selama ini. Dari hasil kuesioner yang telah disebarkan kepada responden $56 \%$ dan $43 \%$ yang menjawab setuju dan sangat setuju terhadap pernyataan diatas.

Selanjutnya, Laporan keuangan yang dihasilkan dari proses Akuntansi dan dikerjakan oleh para Akuntan hanya menyajikan informasi keuangan kepara para pemakai, sedangkan informasi sosial dan lingkungan diabaikan dalam proses akuntansi, menurut Andreas Lako dalam bukunya Green Accounting, bahwa Akuntan hanya menyajikan informasi keuangan saja tapi mengabaikan proses akuntansi yaitu proses informasi sosial dan informasi sosial, hal ini dibuktikan dengan banyak kebakaran hutan, pelapisa ozon 
yang semakin menipis, pencemaran limbah indutri yang pada saat ini telah masuk fase bahaya. Seharusnya sebagai Akuntan harus responsive terhadap informasi sosial dan informasi lingkungan yang berdampak kepada hasil produk yang dihasilkan oleh setiap perusahaan, dari hasil kuesioner yang disebarkan kepada responden terdapat 35\% dan $15 \%$ yang menjawab setuju dan sangat setuju atas pernyataan dibawah sedangkan terdapat $11 \%$ yang menjawab sangat tidak setuju dimana proses Akuntansi dan dikerjakan oleh para Akuntan hanya menyajikan informasi keuangan kepara para pemakai, sedangkan informasi sosial dan lingkungan diabaikan dalam proses akuntansi.

Terakhir pertanyaan mengenai peningkatan eskalasi kerusakan lingkungan, perubahan iklim dan pemanasan global, tekanan politik dan pasar kepada para pemimpin negara dan pebisnis untuk menerapkan konsep Green Economy dan Green Business dalam pembangunan ekonomi/bisnis nasional kian meningkat sebanyak $70 \%$ menyatakan setuju atas penyataan diatas.

\section{SIMPULAN}

Kesimpulannya adalah bahwa terdapat 60 Accounting dan Akuntan yang menjadi sampel dalam penelitian ini. Hasil penelitian ini adalah peningkatan eskalasi kerusakan lingkungan, perubahan iklim dan pemanasan global, tekanan politik dan pasar kepada para pemimpin negara dan pebisnis untuk menerapkan konsep Green Economy dan Green Business dalam pembangunan ekonomi/bisnis nasional kian meningkat sebanyak $70 \%$.

\section{DAFTAR RUJUKAN}

Adams, W.M. (2006). The Future of Sustainability: Re-thinking Environment and Development in the Twenty-first Century. Report of the IUCN Renowned Thinkers Meeting, 29-31 Januari 2006. Diakses pada 19 Desember 2013

Cahyandito, F. (2006). Pembangunan Berkelanjutan, Ekonomi Dan Ekologi, Sustainability Communication Dan Sustainability Reporting. Tersedia di SSRN: http://ssrn.com/abstract=1670708. Diakses pada 19 Desember 2013.

Hanley, N. et. al. (2001). Introduction to Environmental Economics. Oxford University Press, New York. 